\title{
Exploring The Complexity of Student-Created Mind Maps, Based On Science-Related Disciplinary and Interdisciplinary Core Ideas
}

\author{
Helen Semilarski ${ }^{1 *}$, Regina Soobard ${ }^{1}$, Jack Holbrook ${ }^{1}$, Miia Rannikmäe ${ }^{1}$
}

${ }^{1}$ University of Tartu, ESTONIA
${ }^{*}$ Corresponding Author: helen.semilarski@ut.ee

Citation: Semilarski, H., Soobard, R., Holbrook, J., \& Rannikmäe, M. (2021). Exploring the complexity of student-created mind maps, based on science-related disciplinary and interdisciplinary core ideas. Interdisciplinary Journal of Environmental and Science Education, $17(1)$, e2227. https://doi.org/ 10.29333/ijese/ 9153

\section{ARTICLE INFO ABSTRACT}

Received:

3 April 2020

Accepted:

7 September 2020
The success of science education is in promoting conceptualisation, both disciplinary and interdisciplinary, in meeting desired learning goals. This research seeks to identify the quality of, upper secondary school students' dimensions of knowledge and conceptualisation, related to a set of science-related disciplinary and interdisciplinary core ideas. Using validated guidelines, data collected from grade $10(\mathrm{~N}=254)$ students, and an abductive thematic analysis approach are used to subsequently analyse student-created mind maps. Results show that most students are able to create mind maps, although these tend to be very general and indicate few interconnections between the different dimensions of knowledge presented. The results further suggest that, in general, it is difficult for students to conceptualise the interrelationships between science-related disciplinary and interdisciplinary core ideas and even show that some students hold misconceptions. The use of mind maps is seen as a meaningful approach to identifying learners' ability to relate dimensions of knowledge applied to disciplinary and interdisciplinary core ideas in science education. The research identifies a need to investigate learning approaches in secondary school studies so as to promote more emphatically interconnections between disciplinary and interdisciplinary core ideas.

Keywords: conceptualisation, disciplinary core ideas, interdisciplinary core ideas, dimensions of knowledge, mind maps, science education

\section{INTRODUCTION}

In today's society, science is increasingly linked with a wide range of careers paths (OECD, 2016), and developing science conceptualisations are seen as essential in facilitating students' meaningful and motivational learning. One identified problem in science education is thatstudentslackawareness of interrelationshipsbetween their achieved knowledge and the world around them (Harlen et al., 2010), even though they indicate that they do not want to study science as a series of disconnected facts to be learned. In practice, students only focus on thinking and the need to study random facts, because they recognise the need to pass examinations (Harlen et al., 2015). This points to a need for making changes in the manner in which science education is portrayed. This includes establishing interconnections between different dimensions of knowledge (Teppo et al., 2017;
Harlen et al., 2015; Hildebrand, 2018). All such dimensions form a foundation for disciplinary teaching (NRC, 2007). Knowledge is a complex term, potentially referring to 4 major dimensions, often expresses as "knowing (what is; what it means; what to do; what to think)", or categorised as factual, conceptual, procedural, and metacognitive knowledge (Krathwohl, 2002). These dimensions are more meaningfully expressed as stating information, acquiring cognitive abilities, putting forward actions to undertake such as in solving problems, or self-thinking, for example putting forward one's own views during an argumentative discourse. Harlen et al. (2015) suggest that not only do students need to pay attention to applying dimensions of knowledge in multiple situations, but in addition, student development needs to be associated with their enhancement from grade to grade, as well as ways in which these dimensions of knowledge are 
interconnected. Within science curricula, the emphases placed on the different dimensions of knowledge underpin the evolving learning (Bransford, Brown, \& Cocking, 2000; Ruiz-Primo, 2000). The organisation of knowledge thus impacts on outcomes in teaching and education, where more effort invested in the development of instructional strategies is expected to assist students in creating and organising their knowledge structures (Krathwohl, 2002). Students' knowledge cannot be inspected in isolation learning involves changes in the interconnected elements of the knowledge structure. One approach to this is examining the principles of representing, and analysing how, knowledge can be modelled across four dimensions of knowledge within a fundamental idea. Such core ideas, can be linked to form a framework for structuring knowledge.

The dimensions of knowledge can be grouped using collective terminology, such as 'ideas' (Harlen et al., 2015; Krajcik \& Delen, 2017a; NRC, 2012). These ideas, when expressed as central learning areas, thus represent a wide range of factual, conceptual, procedural and metacognitive dimensions of knowledge. Furthermore, in such situations, these ideas can be termed big, or core ideas (ibid) enabling the development of a curriculum framework. These core ideas are fundamental ideas that are necessary for understanding a given science discipline, have broad importance, and can be taught over multiple grade levels (NRC, 2012). Furthermore, the core ideas can relate specifically to a discipline e.g. biology, or be interdisciplinary, applicable across different disciplines. Interrelating core ideas, both disciplinary and interdisciplinary are of major importance in science teaching, allowing curriculum integration that generates an understanding of ideas within, or cutting across disciplines and forming interconnections such as their relationship to the real world (ibid). The integration of disciplinary and interdisciplinary ideas through different disciplines can facilitate proposes solutions to vital complex problems like global climate warming, loss of rainforests and biodiversity, and epidemics of infectious disease (You, Marshall, \& Delgado, 2018). This suggest that teaching and learning, both disciplinary and interdisciplinary - need to be interrelated.

The main focus of this study is to investigate how students conceptualise core ideas, both disciplinary and interdisciplinary, seen as an essential capability for relating science ideas with everyday life, and appreciating science-related careers (Potvin \& Hasni, 2014). One approach to exploring students' conceptualisation of different core ideas and the interrelationships is to challenge students to create mind maps that illustrate the width of their science learning across dimensions of knowledge.

\section{The Aim of the Study}

The aim of this research is to explore students' conceptualisations of science curriculum-related disciplinary core ideas (DCls) and interdisciplinary core ideas (ICls) through examining the complexities of student-created mind maps.

The following research questions are posed:

- RQ1. To what degree of complexity do students conceptualise selected, science curriculum-related, disciplinary and interdisciplinary core ideas?

- RQ2. What science dimensions of knowledge, related to a set of specific disciplinary and interdisciplinary core ideas, are captured in student-created mind maps?

\section{LITERATURE REVIEW \\ Dimensions of Knowledge}

Based on the word "construct", Freedman (1994) indicates that the main idea of constructivist learning is to understand the way we construct knowledge, based on previous experiences and conceptual challenges. Unfortunately, researchers have identified that a lack of meaningful constructs acquired by students can lead to misconceptions, which are seen as obstacles (such as faulty thinking or understanding) to students' meaningful learning (Cho et al., 1985; Gafoor \& Akhilesh, 2008). Misconceptions may occur in the form of an initial concept, where there is an incorrect interrelationship between concepts, and may lead to wrong ideas or views (Chi, 2008). Thus, it is important that the correct interrelationships between the different concepts are formed during the learning process (ibid).

Deconstructing subject content to dimensions of knowledge identifies the structure for understanding concepts and can be important in assisting students to develop knowledge and overcoming misconceptions. These dimensions of knowledge provide a framework for conceptualising different learning areas where conceptualisation is seen as referring to the action, or process of acquiring learning by thinking and interconnecting different dimensions of knowledge. The theory of constructivism points out that we gain knowledge effectively when engaged in the process, thus creating our own knowledge construction (Thompson, 2000; Wilson, 2001).

Krathwohl (2002) indicates that knowledge can be categorised to form 4 dimensions, labelled:

a. Factual - basic elements that include isolated bits of information, or knowledge about specific details.

b. Conceptual - the interrelationship among the basic 
elements within a larger structure that enable them to function together, such as knowledge or understanding of principles, theories, models, classifications, etc.

c. Procedural - how to do something; methods; specifying skills, or technique. The performing (or carrying out) of specific tasks.

d. Metacognitive - knowledge of cognition in general, strategic knowledge, knowledge of cognitive tasks, and self-knowledge.

Within this framework, conceptual knowledge is that acquired in the mind, from experience, reasoning, and imagination and tend to indicate an order for teaching so that students can reach higher levels of thinking (Anderson \& Krathwohl, 2001; Bloom \& Krathwohl, 1956; Krathwohl, 2002). While factual and conceptual knowledge are often taught at school, putting stronger emphasis on procedural and metacognitive knowledge can lead to a wider and deeper conceptualisation, enabling the testing of ideas and gauging the validity of theoretical claims and thus supporting more meaningful learning (Alavi \& Leidner, 2001; Krathwohl, 2002).

\section{Core Ideas in Science Education}

Core ideas can be defined as those ideas by which conceptualisation can help students to learn about the world and themselves (Krajcik \& Delen, 2017a; 2017b) and are seen as fundamental ideas that are necessary for understanding a given science discipline (NRC, 2012). These core ideas can be linked to form a scientific framework for various curriculum topics set out in the Estonian curriculum (Estonian Government, 2011).

Core ideas within, or across science, can relate to societal or personal need (Harlen et al., 2010; NRC, 2007) and, explicitly, can:

(a) enable the formation of an organisational structure for exhibiting learning about conceptualisation and knowledge interconnections, and can help to prepare students for deeper levels of scientific understanding and metacognition from elementary to upper secondary school and beyond (Harlen et al., 2015; NRC, 2012);

(b) enable interconnections at increasing levels of depth and sophistication (forming different hierarchies) and can provide a framework showing how acquired knowledge are interconnected to form the whole (AAAS, 2001);

(c) be valuable in that these can be used as thinking tools (for illustrating the interconnections) and hence can be indispensable in explaining the problems related to societal and personal concerns, and to generate and implement solutions (Krajcik \& Delen, 2017a; 2017b).

(d) have broad importance across multiple learning disciplines (Cooper et al., 2012; Soobard et al., 2018; Stevens et al., 2009).

A number of authors (Krajcik \& Delen, 2017a; NRC, 2012; Semilarski et al., 2019) propose that core ideas can be sub-divided into two different types:

a) disciplinary core ideas (DCIs), which are linked with specific science disciplines and can be taught over multiple grade levels at progressive levels of complexity. e.g. core ideas in biology, such as heredity, (or more specifically, as DNA); core ideas in chemistry, such as chemical reactions.

b) interdisciplinary core ideas (ICls), which are transferrable across different subjects e.g. the core idea of models, systems, or patterns, yet are also central in facilitating learning. While other authors have named these as cross-cutting concepts (Krajcik \& Delen, 2017a; NRC, 2012), interdisciplinary core ideas can be seen as a better way to express that core ideas have transferability across different subject disciplines. Thus ICls are much broader in scope than disciplinary core ideas and are not necessarily solely rooted in science. e.g. the knowledge gained while using models and the understanding of model development and its implementations, are transferable to the learning processes in other disciplines.

Stevens and his colleagues (2009) recognise that it is meaningful to be able to break down core ideas, as well as establishing that each core idea can be expected to interrelate with other core ideas to form a more meaningful appreciation, through which students can make sense of the world (NRC, 2012). In this manner, core ideas in different science subjects can be expected to make interconnections, even with other disciplines and this needs to be recognised by both teachers and students. You, Marshall \& Delgado, (2018) point out the importance of students learning about a single core idea from a variety of different viewpoints and in different disciplines.

\section{Mind Maps}

Although initially mind maps are seen as an approach that relates imagination with structure through reason (Ausubel, 1968; Brinkmann, 2003), the technique has been further developed so as to determine students' potential to arrange and organise that taught (Buzan, 2009a; 2009b). In mind maps, the main idea (core idea) is broken down to emphasise the interconnections formed from individual dimensions of knowledge (Ausubel, 1986; Buzan, 2009a; 2009b; Erdem, 2017, Kinchin, 2011; Novak \& Gowin, 1984). These interconnections can include ideas, keywords, codes, and symbols (Brinkmann, 2003). Mind maps have three basic features (Buzan, 2005; Buzan \& Buzan, 2007):

a) a core idea $(\mathrm{DCl}$ or $\mathrm{ICI})$, placed at the centre of the mind map; 
b) the central core idea branches into one or more specific dimensions of knowledge, where these dimensions of knowledge may or not be interconnected;

c) interconnections are formed, (similar to tree roots), having:

(i) both vertical and horizontal interconnecting boxes, representing interrelated ideas;

(ii) complexity in the form of interconnected horizontalandverticalboxes forming hierarchies. New hierarchical layers are built from the old layers, giving an increased complexity;

(iii) the network of dimensions of knowledge are interconnected with the core idea ( $\mathrm{DCl}$ or ICl) by arrows.

Central concepts can be formed when arrows from any dimensions of knowledge link that dimension to more than one other dimension (Kinchin, 2011). The higher the number of central concepts shows the more extensive the mind maps in terms of hierarchy and number of links and specific. The mind map indicates the visualisation of students' thinking and understanding of processes related to core ideas within science content (ibid.). The focus is thus on creating a visual representation of how relationships exist between different dimensions of knowledge.

Previous research has shown that the mind map teaching approach has been shown to be successful, with students more extensively and thematically organized, and able to more richly portray interconnectedness of thoughts and dimensions of knowledge (Dhindsa, Makarimi-Kasim, \& Anderson, 2010). Schwendimann (2015) indicates that mind maps can support knowledge integration processes by eliciting identification of core ideas and interconnections and making visible possible clusters, or hierarchies. The mind map technique makes it possible to capture knowledge in small units (Buzan \& Buzan, 2007). Such units can hold various types of dimensions of knowledge. Thus, through analysing student-created mind maps, there is an opportunity to assess learning, providing indications of the cohesion and contingency of the relational structure of students' knowledge, as well as enhancing long-term learning outcomes, retention and transfer.

\section{METHOD}

This research explores student-created mind maps involving disciplinary and interdisciplinary core ideas so as to determine students' ability to express dimensions of knowledge, associated with core ideas.

\section{Sample}

The sample consisted of 254 students, from 6 different Estonian schools, in 8 grade 10 classes, each class being in a separate, purposive selected school. All students undertook the same teaching-learning curriculum prior to data collection based on the same competence-based science curriculum designed to promote scientific literacy (Estonian Government, 2011). The curriculum focussed on both the dimensions of Bloom's revised taxonomy and the knowledge components (Krathwohl, 2002).

\section{Instrument Development}

To identify suitable core ideas which could be used by students to develop mind maps, the researchers: initially selected, from the Atlas of Science Literacy (AAAS, 2001) conceptual strand maps for each of 4 science disciplinary core ideas (total32), as well as 8 interdisciplinary core ideas, seen as relevant within the Estonian national curriculum (2011). After the selection of core ideas researchers created a Google Form questionnaire using the selected 40 core ideas ( 32 disciplinary and 8 interdisciplinary, core ideas); the created questionnaire included both closed questions (respondents had to choose from the list 10 most important core ideas) and open-ended questions (respondents had to justify their choice). Thequestionnaire was administered to 12 science teachers ( 3 from each sub-discipline) separately and also 4 science educators to identify, in their opinion, the two most important core ideas for each of the 4 science disciplines (total 8) and also two important interdisciplinary core ideas. The teachers and science educators were requested to make their selection based on the following:

i. the 2 disciplinary core ideas, within a specific -discipline were interconnected, and seen as important for a future workforce;

ii. the interdisciplinary core ideas were important across multiple science disciplines;

iii. the DCIs and ICls were associated with the Estonian national curriculum;

iv. the $\mathrm{DCls}$ and $\mathrm{ICls}$ were applicable across multiple grades at increasing levels of depth and sophistication (thus important in understanding the world).

Based on those most frequently identified, the following DCls and ICls were selected for grade 10 student elaboration through mind maps:

a. DCIs in biology (life science) - genetic variation and DNA/heredity;

b. DCls in chemistry - characteristics of substances and chemical reactions;

c. DCls in geography (earth science) - weather/climate and land surface changes; 
d. DCls in physics - energy conversion and motions/ waves;

e. ICls - models and systems.

\section{Data Collection}

Prior the data collection. Prior to being asked to develop mind maps, each grade 10 class was instructed in the methods of presenting a mind map by their science teacher. As an aid, each teacher distributed a description of the visualisation procedure to each student. Teachers who were included in the sample were asked to participate in an in-service training course, during which they were given an overview of the nature of mind maps and guided how to use this technique with their students. Following the instruction, each student practiced creating a mind map. For this, students were each given a sheet of paper with the word "sustainability" printed in the middle and asked to create a mind map about "sustainability" to include its explanation, various meaning and associations. The students were not given any further guidance and were asked to complete the mapping task during a normal lesson, i.e. within 45 minutes. This "sustainability" task enabled students to practice the mind mapping method (including drawing arrows and making connections) using a familiar term which can be taken to be an interdisciplinary core idea.

Data collection. For the main data collection, exercise in a subsequent lesson, each student was presented with one core idea, selected randomly from a set of 10 provided by the researchers. The students were asked, "How do you conceptualise the given core idea?". By applying your knowledge and skills, create an appropriate scheme similar to that previous demonstrated as a mind map. Students were given 45 minutes to create their mind maps, this task being administered during one science lesson.

\section{Analysis of Mind Maps}

Abductive thematic analysis, combining theory and empirical data, is used (Tavory \& Timmermans, 2014). in which the theory and empirical facts are reinterpreted in the light of each other (Tayaben, 2018). The basic process in the abductive analysis is seen as bringing together similar data within the framework of the specified disciplinary or interdisciplinary core ideas so as to interpret the findings in a way that the reader can understand. The analysis of student-created mind maps is based on determining how far students are able to interconnect their subject learning (Kinchin \& Hay, 2000) and be able to demonstrate a coherent conceptualisation of the core ideas, in terms of number of interconnections (links) per each of the different, more complex hierarchies, labelled 1-4 (shown in Table 1). A count of hierarchies, indicated by students in their mind maps, (Table 1) involves the determination of:

a. vertical and horizontal interconnection of boxes, ideas;

b. the complexity of the map (radial), (linear- radial over more than 1 hierarchy), (integrated but limited to one linearity), (multiple integrated).

The analysis measured the complexity of the map, indicating the degree to which students can conceptualise the $\mathrm{DCl}$ or $\mathrm{ICl}$ the frequency of the dimensions of knowledge overall and how often different dimensions of knowledge are reflected in the students' mind maps.

The students' dimensions of knowledge (Krathwohl, 2002) were analysed to identify different learning and determine students' higher levels of thinking. For this, maps were examined to determine whether the following were present (Figure 1, parts 1 and 2, given as an illustration):

a. factual knowledge - the basic elements include isolated bits of knowledge (for the most part single words connected to core ideas). These include knowledge of terminology, specific details, and elements;

b. conceptual knowledge - the interrelationships among the basic knowledge within a larger structure (for the most part these tend to be called central concepts). Including knowledge of classifications, categories, principles, generalisations, theories, and structures;

c. procedural knowledge - how to do something: methods, techniques. Including knowledge of subject-specific skills, techniques, and methods.

d. misconceptions - view or opinion that is incorrect based on faulty thinking or understanding;

e. central concepts - branches (or breaks down) into more specific dimensions of knowledge that may or are not interconnected.

\section{Validity and Reliability}

The validity of the created instrument was enhanced by

- students being familiar with mind maps (i.e. having an opportunity to practice mind mapping beforehand);

- task given in a concrete and clear manner;

- DCls and ICls, used for mind mapping, selected for relevance by experts (science teachers and science educators from the University of Tartu);

- all DCls and ICls taken from the Estonian curriculum thus ensuring all students having prior knowledge of them.

Determined hierarchies and dimensions of knowledge 
Table 1. Four types of mind maps given in hierarchical order

\section{A radial structure - in which:}

(a) all the related aspects are linked directly to the $\mathrm{DCl}$ or

$\mathrm{ICl}$, but not directly linked with each other;

(b) are only formed by linking specific dimensions of knowledge

(b) dimensions of knowledge are not inter-connected;

(c) (connections /links/arrows) do not cross;

(d) interconnection of boxes are vertical and not horizontal.

\section{A linear sequence- in which:}

(a) radial and horizontal interconnections;

(b) each $\mathrm{DCl} / \mathrm{ICl}$ is only linked to a sub-idea, or dimensions of knowledge immediately above and below; (c) though a logical sequence exists from beginning to end, the implied hierarchical nature of many links is not valid;

(d) interconnections only with the next following;

(e) the interconnection of boxes are vertical and not horizontal.

\section{An integrated and hierarchical network - in which:}

(a) radial and horizontal interconnections;

(b) demonstrates some deeper conceptualisation of the $\mathrm{DCl} / \mathrm{ICl}$;

(c) the network is structured across different hierarchies with interconnections;

(d) indicates deep understanding;

(e) the complexity of the map radial), (linear-radial over more than 1 hierarchy), (integrated but limited to one linearity), (multiple integrated).
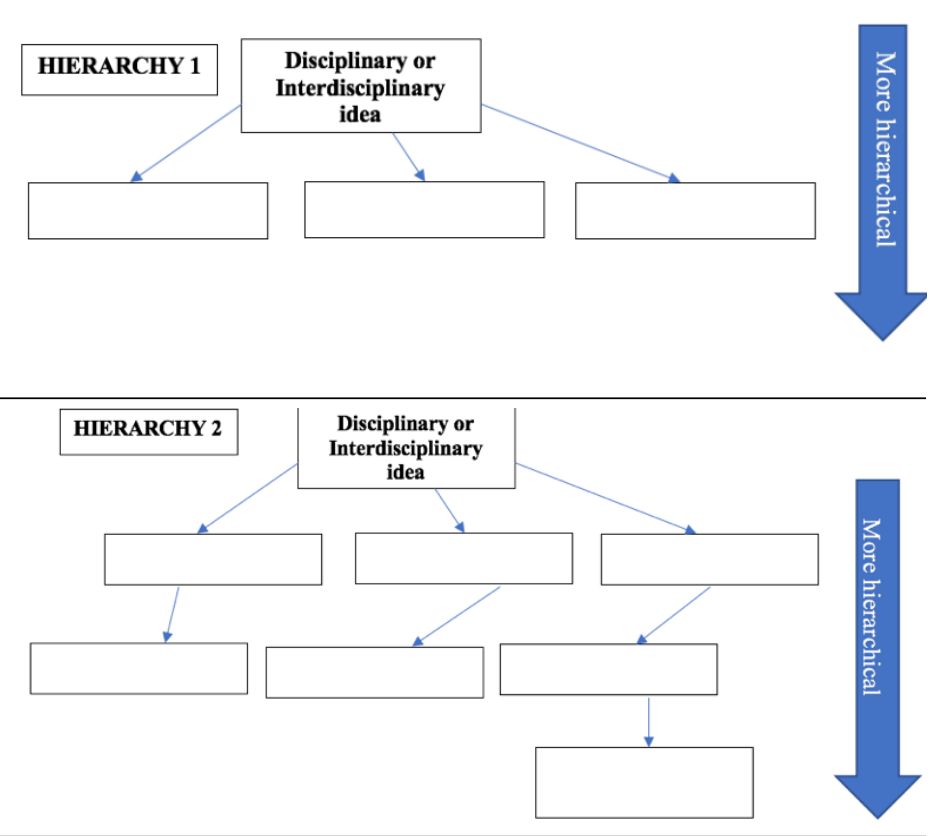

\section{A multiple integrated and hierarchical network - in} which:

(a) radial and horizontal interconnections;

(b) demonstrates a multiply deeper understanding of the

$\mathrm{DCl}$ and $\mathrm{ICl}$;

(c) the network is structured across different hierarchy with interconnections;

(d) indicates deep understanding and meaningful learning;

(e) the complexity of the map radial), (linear- radial over more than 1 hierarchy), (integrated but limited to one linearity), (multiple integrated).

were validated through expert opinion (four scientists from the University of Tartu). The percentage agreement between four experts (science educators from the University of Tartu) was over $70 \%$. The reliability of the mind maps analysis was identified by expert opinion by abductive thematic analysis (about hierarchies and dimensions of knowledge). The reliability of the data analysis was determined by cross-checking, from outputs by the abductive thematic analysis against expert opinion, (giving the initial coding of presented hierarchies and dimensions of knowledge).

\section{RESULTS}

Table 2 provided data on the number and type of hierarchies 1st - 4th created (from more general to more specific), the number of links (interconnections), showing how a variety of students drawn dimensions of knowledge were connected, and central concepts, which were broken down into more specific dimensions of knowledge. All students gave mind maps covering the 1st hierarchy, but less than half gave a map covering the 2nd hierarchy, only a few students indicated a 3rd hierarchy, while virtually no student (actually a total of 3 ), were able to indicate a 4th hierarchy. The total links per $\mathrm{DCl}$, or 


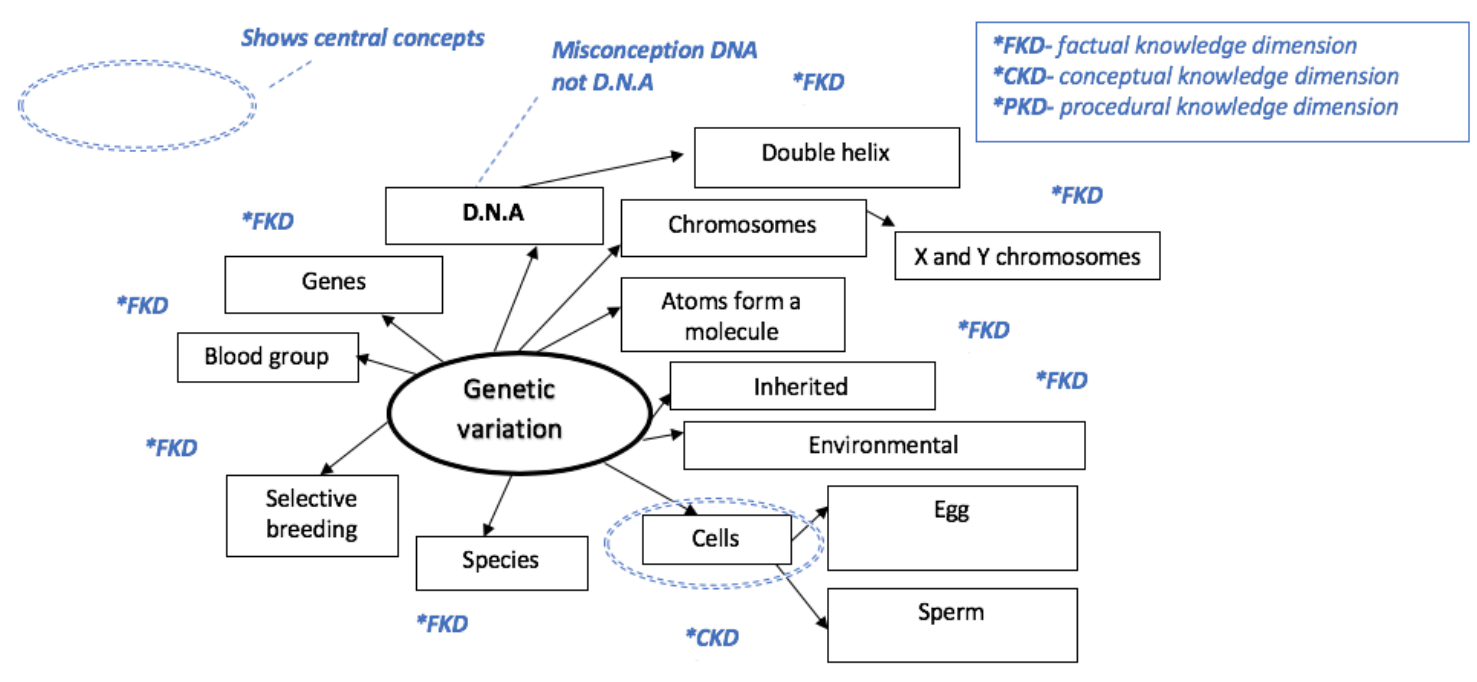

(1)

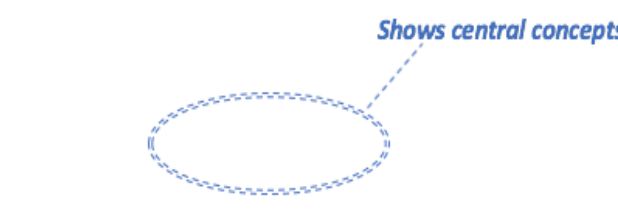

*PKD- procedural knowledge dimension

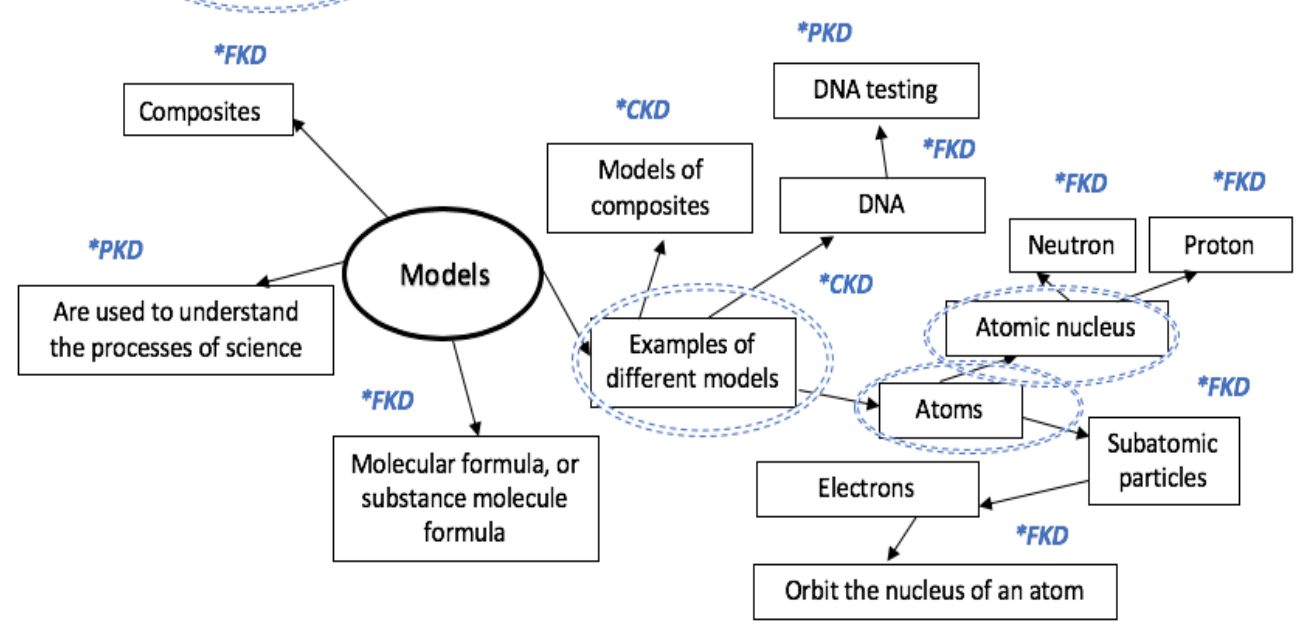

(2)

Figure 1. Illustrative samples of student-created mind map showing: (1) DCI (genetic variation) and (2) ICI (models). The asterisked labelling shows the dimensions of knowledge. The circles show (a) given $\mathrm{DCl}$ or $\mathrm{ICl}$ (with a thick line) and (b) central concepts (dashed line)

$\mathrm{ICl}$, as well as the average number of links per students differed per student. Table 2 showed averages for better comparability between different DCIs and ICls. Only in the case of DNA and Weather and climate were mind maps of hierarchy 4 created. Results also indicated that fewer interconnections (links per student) were formed with the DCls characteristics of substances and energy conversion. More interconnections (links per student) were indicated with the DCls, such as weather and climate; DNA: heredity, and genetic variety. Fewer central concepts (per student) were formed with the DCls characteristics of substances and with motions: waves. Students also formed more central concepts (per student) with the DCls weather and climate and genetic variation. This showed that students made more interconnections with core ideas related to biology and geography and fewer with core ideas related to chemistry and physics.

Table 3 showed more specifically how grade 10 students conceptualised each $\mathrm{DCl}$ or $\mathrm{ICl}$, in terms of dimensions of knowledge within their created mind maps. For each dimension of knowledge (factual, conceptual, procedural), the frequency of number of times students indicated a specific dimension in his/her created $\mathrm{DCl} / \mathrm{ICI}$ mind map about $\mathrm{DCl}$ or $\mathrm{ICl}$ were determined. Also, the number of students responding to each $\mathrm{DCl}$ and $\mathrm{ICl}$ were included, plus any student misconceptions per DCI and ICI were determined and analysed.

Results showed (Table 3) students indicated 
Table 2. Overall outcomes from mind maps drawn by students, indicating the number of mind maps per hierarchies (1st - 4th), total links (interconnections) per core idea/per student (average) and central concepts per core idea/per student (average)

\begin{tabular}{|c|c|c|c|c|c|c|c|c|c|}
\hline & Core idea & $\begin{array}{l}\text { 1st } \\
\text { freq }\end{array}$ & $\begin{array}{l}\text { 2nd } \\
\text { freq }\end{array}$ & $\begin{array}{l}\text { 3rd } \\
\text { freq }\end{array}$ & $\begin{array}{l}\text { 4th } \\
\text { freq }\end{array}$ & $\begin{array}{l}\text { Total links } \\
\text { per DCI/ } \\
\text { ICI }\end{array}$ & $\begin{array}{l}\text { Links per } \\
\text { student }\end{array}$ & $\begin{array}{l}\text { Central } \\
\text { concepts } \\
\text { per DCI/ } \\
\text { ICI }\end{array}$ & $\begin{array}{l}\text { Central } \\
\text { concepts } \\
\text { per } \\
\text { student }\end{array}$ \\
\hline \multirow{2}{*}{ 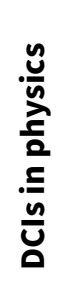 } & $\begin{array}{l}\text { Energy } \\
\text { conversion } \\
(n=24)\end{array}$ & $\begin{array}{l}152 \\
(n 1=24)\end{array}$ & $\begin{array}{l}104 \\
\text { (n2=9) }\end{array}$ & $\begin{array}{l}44 \\
(n 3=2)\end{array}$ & $\begin{array}{l}0 \\
(n 4=0)\end{array}$ & 300 & 12.50 & 63 & 2.63 \\
\hline & $\begin{array}{l}\text { Motions: } \\
\text { Waves } \\
(n=24)\end{array}$ & $\begin{array}{l}218 \\
(n 1=24)\end{array}$ & $\begin{array}{l}119 \\
(\mathrm{n} 2=10)\end{array}$ & $\begin{array}{l}0 \\
(\mathrm{n} 3=0)\end{array}$ & $\begin{array}{l}0 \\
(n 4=0)\end{array}$ & 327 & 13.63 & 54 & 2.25 \\
\hline \multirow{2}{*}{$\begin{array}{l}\frac{\dot{0}}{0} \\
\frac{0}{0} \\
\frac{u}{U}\end{array}$} & $\begin{array}{l}\text { Genetic } \\
\text { variation } \\
(n=17)\end{array}$ & $\begin{array}{l}208 \\
(n 1=17)\end{array}$ & $\begin{array}{l}98 \\
(\mathrm{n} 2=8)\end{array}$ & $\begin{array}{l}38 \\
(n 3=2)\end{array}$ & $\begin{array}{l}0 \\
(n 4=0)\end{array}$ & 344 & 20.24 & 60 & 3.53 \\
\hline & $\begin{array}{l}\text { DNA } \\
(n=16)\end{array}$ & $\begin{array}{l}160 \\
(\mathrm{n} 1=16)\end{array}$ & $\begin{array}{l}89 \\
(n 2=4)\end{array}$ & $\begin{array}{l}51 \\
\text { (n3=3) }\end{array}$ & $\begin{array}{l}40 \\
(n 4=2)\end{array}$ & 340 & 21.25 & 56 & 3.50 \\
\hline \multirow{2}{*}{ 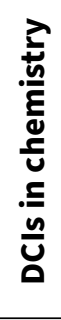 } & $\begin{array}{l}\text { Chemical } \\
\text { reactions } \\
(n=30)\end{array}$ & $\begin{array}{l}227 \\
(n 1=30)\end{array}$ & $\begin{array}{l}95 \\
(\mathrm{n} 2=17)\end{array}$ & $\begin{array}{l}65 \\
(n 3=9)\end{array}$ & $\begin{array}{l}0 \\
(n 4=0)\end{array}$ & 387 & 12.90 & 87 & 2.90 \\
\hline & $\begin{array}{l}\text { Character- } \\
\text { is-tics of } \\
\text { substances } \\
(n=34)\end{array}$ & $\begin{array}{l}161 \\
(\mathrm{n} 1=34)\end{array}$ & $\begin{array}{l}97 \\
(\mathrm{n} 2=16)\end{array}$ & $\begin{array}{l}54 \\
(n 3=3)\end{array}$ & $\begin{array}{l}0 \\
(n 4=0)\end{array}$ & 312 & 9.18 & 69 & 2.03 \\
\hline \multirow{2}{*}{ 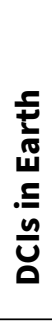 } & $\begin{array}{l}\text { Land } \\
\text { surface } \\
\text { changes } \\
(n=29)\end{array}$ & $\begin{array}{l}272 \\
(n 1=29)\end{array}$ & $\begin{array}{l}186 \\
(n 2=16)\end{array}$ & $\begin{array}{l}71 \\
(\mathrm{n} 3=3)\end{array}$ & $\begin{array}{l}0 \\
(n 4=0)\end{array}$ & 529 & 18.24 & 87 & 3.00 \\
\hline & $\begin{array}{l}\text { Weather } \\
\text { and climate } \\
(n=28)\end{array}$ & $\begin{array}{l}255 \\
(n 1=28)\end{array}$ & $211(\mathrm{n} 2=15)$ & $\begin{array}{l}99 \\
(n 3=6)\end{array}$ & $31(n 4=1)$ & 596 & 21.29 & 105 & 3.75 \\
\hline \multirow[b]{2}{*}{$\underline{\underline{u}}$} & $\begin{array}{l}\text { Models } \\
(n=31)\end{array}$ & $\begin{array}{l}270 \\
(n 1=31)\end{array}$ & $\begin{array}{l}142 \\
(\mathrm{n} 2=13)\end{array}$ & $\begin{array}{l}40 \\
(n 3=1)\end{array}$ & $\begin{array}{l}0 \\
(n 4=0)\end{array}$ & 452 & 14.58 & 85 & 2.74 \\
\hline & $\begin{array}{l}\text { Systems } \\
(n=21)\end{array}$ & $\begin{array}{l}216 \\
(n 1=21)\end{array}$ & $\begin{array}{l}142 \\
(\mathrm{n} 2=13)\end{array}$ & $56(n 3=4)$ & $\begin{array}{l}0 \\
(\mathrm{n} 4=0)\end{array}$ & 414 & 19.71 & 64 & 3.05 \\
\hline
\end{tabular}

*Frequency (freq) indicates how many interconnections (links) students made in their created mind map; n1 indicates how many students reached the 1 st hierarchy, $\mathrm{n} 2$ the 2 nd hierarchy, $\mathrm{n} 3$ the $3 \mathrm{rd}$ hierarchy and $\mathrm{n} 4$ the 4 th hierarchy; $\mathrm{n}$ indicates how many students created mind maps about disciplinary and interdisciplinary core ideas.

interconnections with factual, conceptual and procedural dimensions of knowledge. Factual knowledge was the most frequently dimension of knowledge depicted. Results also indicated that students did not make any interconnections incorporating metacognition and students held 128 misconceptions about all DCIs and ICls. An example of a student created mind map about genetic variation was as shown in Figure 2. The created mind map was 4th level, multiple integrated and hierarchical network, which demonstrated deep understanding of the core idea.
As gender-wise differences were not detected in the analysis of the created mind maps, gender-wise outcomes were not included in this research.

\section{DISCUSSION}

The aim of this research was to explore how students conceptualised both disciplinary core ideas (DCls) and interdisciplinary core ideas (ICls) through the use of student-created mind maps. Based on Buzan's (2005, Buzan \& Buzan, 2007) suggestion that the complexity of the student-created mind map indicated the degree to 
Table 3. Students' frequency of inclusion of the 3 dimensions of knowledge and misconceptions for each $\mathrm{DCl}$ or ICl

\begin{tabular}{|c|c|c|c|c|c|c|}
\hline & & $\begin{array}{l}\text { No of } \\
\text { students } \\
\text { responding } \\
\text { for each DCI } \\
\text { or ICI }\end{array}$ & $\begin{array}{l}\text { Factual } \\
\text { freq }\end{array}$ & $\begin{array}{l}\text { Conceptual } \\
\text { freq }\end{array}$ & $\begin{array}{l}\text { Procedural } \\
\text { freq }\end{array}$ & $\begin{array}{l}\text { Misconcep- } \\
\text { tions } \\
\text { freq }\end{array}$ \\
\hline \multirow[t]{2}{*}{ DCIs in physics } & Energy conversion & $(n=24)$ & 176 & 50 & 25 & 9 \\
\hline & Motion: waves & $(n=24)$ & 213 & 157 & 28 & 19 \\
\hline \multirow[t]{2}{*}{ DCls in biology } & Genetic variation & $(n=17)$ & 172 & 124 & 30 & 12 \\
\hline & DNA & $(n=16)$ & 169 & 122 & 23 & 16 \\
\hline \multirow[t]{2}{*}{ DCIs in chemistry } & Characteristics of substances & $(n=30)$ & 169 & 114 & 19 & 9 \\
\hline & Chemical reactions & $(n=34)$ & 188 & 145 & 33 & 21 \\
\hline \multirow{2}{*}{$\begin{array}{l}\text { DCls in Earth } \\
\text { science }\end{array}$} & Land surface changes & $(n=29)$ & 296 & 215 & 49 & 9 \\
\hline & Weather and climate & $(n=28)$ & 322 & 185 & 77 & 11 \\
\hline \multirow[t]{3}{*}{ ICls } & Models & $(n=31)$ & 310 & 105 & 20 & 10 \\
\hline & Systems & $(n=21)$ & 226 & 148 & 28 & 12 \\
\hline & Total & $(n=254)$ & $\begin{array}{l}2241 \\
(55.1 \%)\end{array}$ & $\begin{array}{l}1365 \\
(33.6 \%)\end{array}$ & $\begin{array}{l}332 \\
(8.2 \%)\end{array}$ & $\begin{array}{l}128 \\
(3.1 \%)\end{array}$ \\
\hline
\end{tabular}

*Frequency (freq) indicates how many factual, conceptual or procedural dimensions of knowledge and misconceptions students indicated in their created mind maps.

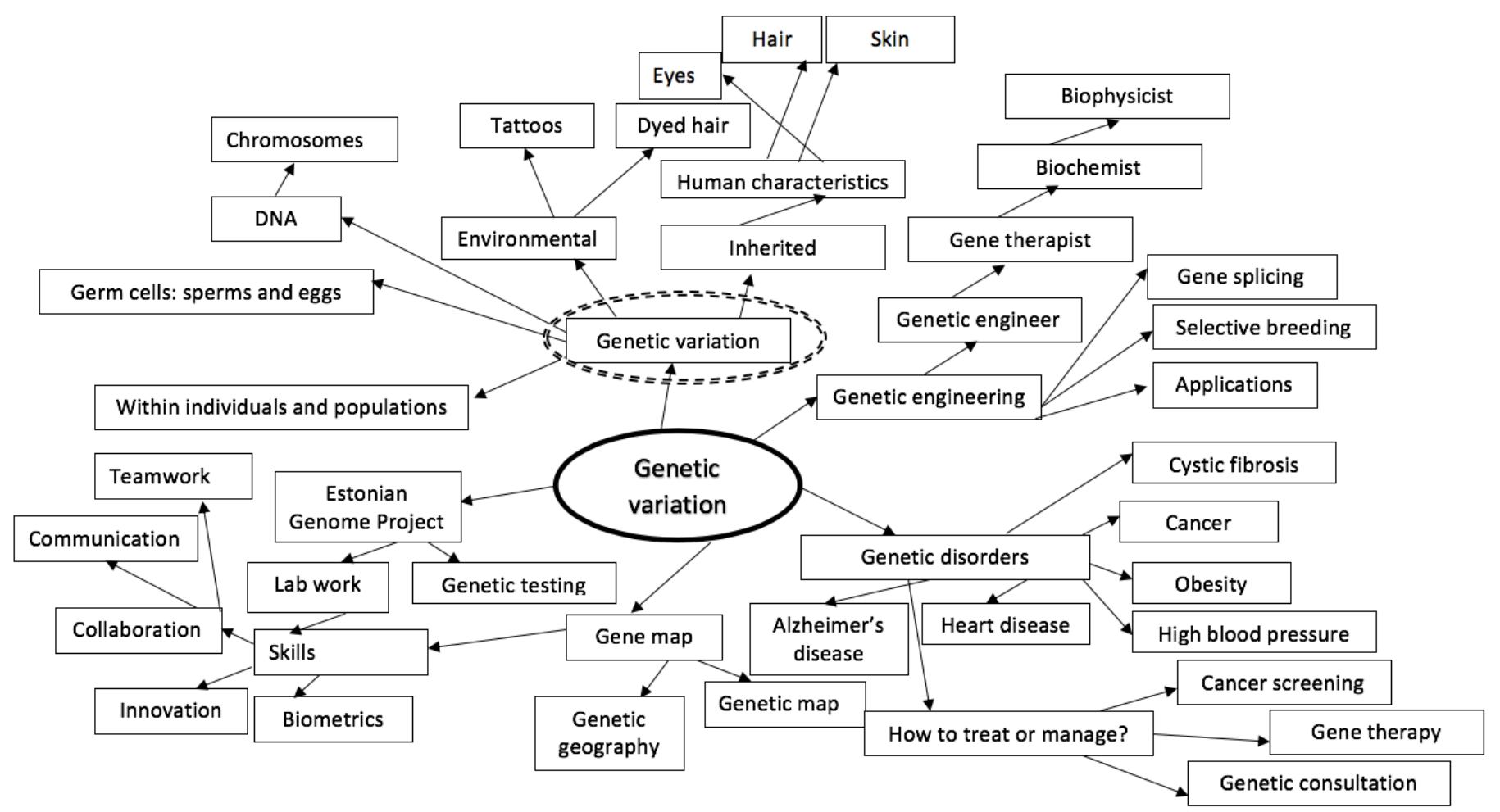

Figure 2. Illustrative sample of 4 th level student-created mind map

which students conceptualised the specific $\mathrm{DCl}$ or $\mathrm{ICl}$, this research explored the degree to which links were made to the 4 different dimensions of knowledge stated by Krathwohl (2002). Each $\mathrm{DCl}$ and $\mathrm{ICl}$ was expected to be conceived by students as a framework for different dimensions of knowledge, and was thus used to explore 
the extent of students' ability to break down the ideas into sub-ideas and eventually ending with factual components. This research was seen as important, noting that the dimensions of knowledge within the Estonian curriculum focused on the need for students to design solutions to problems which required students to create, modify and then improve their solutions, thereby being able to draw on clear science conceptualisations (Estonian Government, 2011).

Table 2 showed that all students were able to draw mind maps with a radial structure (i.e. hierarchy 1 as per table 1). But only about half the students were also able to go further and construct a higher hierarchical mind map in each of the 10 core ideas supplied. In the simpler radial mind maps, the average number of links was approximately 8 , rising to an average of 11 links for linear maps (hierarchy 2). For the few students $(n=33)$ who compiled integrated/hierarchical mind maps, the average number of links increased to 18 and for the 3 students who created multiple integrates/hierarchical (hierarchy 4) i.e. mind maps for DNA or weather: climate, the links were over 20. By and large, the most difficult DCls for forming links were those in the chemistry field, although no student was able to create an integrated/hierarchical or higher mind map for the $\mathrm{DCl}$ - motions: waves. The results pointed to most students holding fragmental knowledge of different core ideas, unable to portray a clear picture linking the $\mathrm{DCls}$ or ICls to multiple related dimensions of knowledge (Cooper, Posey, \& Underwood, 2012; Harlen et al., 2015; Kinchin \& Hay, 2000). The above was in line with previous research, which showed that students had difficulties in different science subjects to interconnect different dimensions of knowledge to one overarching core idea (Soobard \& Rannikmäe, 2015). This suggested that insufficient emphasise was being placed on conceptualisation of core ideas in science teaching so that students were able to interconnect different science, or interdisciplinary, ideas. Harlen (2015) recognised that students needed to be provided with the opportunities to build a network of interconnected and contextualised ideas, such that if students themselves needed to subsequently call on these ideas, they were better able to relate conceptual knowledge.

Kinchin (2011) suggested that the higher the number of central concepts formed in the student-created mind maps, the more the maps were seen as hierarchical and more specific. Table 2 showed that the studentcreated mind maps included few central concepts. More specifically, it showed that fewer central concepts (per student) were formed with characteristic of substances and with motions: waves, whereas students formed more central concepts (per student) within the core ideas
- weather/climate and genetic variation. This finding could be associated with the more general or abstract nature of the mind maps for DCls in physics and chemistry. Such a result could indicate that teaching, especially in physics and chemistry, was based on different isolate core ideas, rather than establishing interconnections to support the greater conceptual acquisition associated with core ideas. In this respect, it was noted that the Estonian curriculum was concept-based, with the learning areas being perceived to be more abstract and less experience-based in the case of chemistry and physics curricula (Estonian Government, 2011). In this situation students were able to interlink different dimensions of knowledge to depict more complex interconnections.

Table 3 showed that the student=created mind maps included factual, conceptual and procedural dimensions of knowledge. More specifically, it showed that students highlighted more factual knowledge interconnections (55.1\%), rather than conceptual (33.6\%), or procedural knowledge (8.2\%). It was clear that, for the most part, students did not link the $\mathrm{DCl}$ and $\mathrm{ICl}$ with procedural knowledge, which involved knowledge of skills. Such a result might indicate science was presented as a collection of facts and that teachers emphasised factual knowledge rather than conceptual and procedural (Harlen et al., 2010). This was seen as a matter of concern, because these dimensions of knowledge gave a framework for understanding different learning areas and possibly an order for teaching so that students could reach higher levels of thinking (Anderson \& Krathwohl, 2001; Bloom \& Krathwohl, 1956; Krathwohl, 2002). A possible reason why students indicated more factual knowledge than other dimensions of knowledge, might be that schools did not pay much attention to the development of competences (knowledge, skills, attitudes, and values) above and beyond content acquisition (Harlen et al., 2010; 2015).

It was noted (Table, 3) that no student included metacognitive dimension of knowledge in their created mind maps. This was perhaps not surprising as the Estonian curriculum (2011) placed low emphasis on metacognition. In turn, it meant that teachers placed low emphasis on this in school lessons. Such findings were seen as a matter of concern, because metacognition was seen as important to process thoughts and feelings and in enabling students to conceptualise how to best learn (Anderson \& Krathwohl, 2001; Bloom \& Krathwohl, 1956; Krathwohl, 2002). Furthermore, these researchers recognised that students who utilised metacognitive strategies were more aware of their own thinking, and more likely to be active learners and able to learn more deeply (ibid). The lack of students' recognition of the need for metacognition pointed to a greater emphasis 
being needed on interrelating different dimensions of knowledge (Kinchin \& Hay, 2000).

Guiding students to acquire and integrate new conceptual knowledge has been an important aspect of learning (Krathwohl, 2002; NRC, 2012). When students are learning, they relate new knowledge to that already known, organising that knowledge, and then making its acquisition part of their long-term memory. Thus, it has been important to support students in making interconnections during learning activities (NRC, 2012). When teaching and learning new ideas, it is important to show how these relate to what they have learned in the past (Krajcik \& Delen, 2017a; NRC, 2007). Revisiting DCIs and ICIs in science lessons, as often as possible, means that the interconnections between these ideas and dimensions of knowledge are strengthened, helping students to make sense of what they are learning (Semilarski et al., 2019).

Table 3 showed that students held 128 misconceptions about all DCls and ICls. These misconceptions could be seen as obstacles to students' meaningful learning (Alavi \& Leidner, 2001; Cho et al., 1985; Gafoor \& Akhilesh, 2008). As they showed students' views or opinions were based on faulty thinking, or understanding. For example, in this study, some students indicated "DNA is a cell" and "DNA is an example of RNA" or "atom and molecule are the same". This was seen as alarming, yet further analysis of table 3 showed that more misconceptions were created related with the chemical reactions (e.g. "elements can form other elements") and waves: motions (e.g. "high frequency oscillation is perceived as low tone"). Far fewer misconceptions were illustrated in mind maps on energy conversion (although. "energy cannot be transformed" occurred). The misconceptions might occur because of the fragmented nature of the teaching in which dimensions of knowledge were broken into separate parts in a disorganised manner) and hence this illustrated how ideas associated with $\mathrm{DCl}$ and $\mathrm{ICl}$ were poorly taught across different disciplines, or even within the discipline (Cooper et al., 2012). The problem could thus lie with the nature of the teaching and assessment, this often-targeting individual and isolated knowledge, while refraining from targeting the whole core idea (Harlen et al., 2015). The researchers also examined the studentcreated mind maps in such a way that there are gender differences in the mind maps. As gender differences did not occur and the boys and girls created mind maps were similar, then gender-wise outcomes were not included in this research. As gender differences in mind mapping have not been extensively studies, thus more emphasis should be on this area in future research.

\section{CONCLUSION}

In general, students found it hard to conceptualise the interlinking of dimensions of knowledge for different DCls and $\mathrm{ICls}$ and in some cases, indicated misconceptions held by students. The analysis showed that good student-created mind map indicated many hierarchies (ranging from hierarchies 1 to 4), although in most cases students had difficulties to go beyond radial maps seen as the lowest hierarchical structure. It showed that student-created mind maps were not so complex and illustrated little in-depth. Overall, the research showed that students needed more support (to show how learned core ideas were interconnected) from their science teachers. The research findings further showed that most interconnections were made with factual knowledge lacking the involvement of central concepts and omitting procedural dimensions of knowledge. Generally, the findings revealed that most students lack the ability to related conceptual and procedural knowledge to core ideas. Furthermore, the student-created mind maps did not make any interconnections based on metacognition. That was seen as an important outcome, especially when recognising that science education needed to support and enable students to conceptualise how to best learn.

\section{RECOMMENDATIONS}

Based on the research findings, it is recommended that:

1. Science teachers and educators, especially in science education programmes, place more importance on the development and interlinking of conceptual, procedural and metacognitive knowledge. It is suggested that this can be accomplished by teachers providing more opportunities for students to clarify their understanding by creating a learning environment through disciplinary and interdisciplinary core ideas;

2. More emphasis is placed on ensuring students do conceptualise different disciplinary and interdisciplinary core ideas within science teaching rather than treating these as factual knowledge, thus making it easier for students to interconnect different dimensions of knowledge and thus learn more effectively avoiding the forming of misconceptions;

3. Students are provided with opportunities to build a network of ideas (such as by drawing mind maps) that are interconnected and contextualised in such a way that students are able to call upon the ideas that they have been taught at a subsequent time.

4. Professional development courses are provided to enhance the conceptualisation of disciplinary and interdisciplinary core ideas more successfully in science lessons, by guiding teachers to ensure students 
conceptualise disciplinary and interdisciplinary core ideas and how to promote this in the teaching process.

\section{LIMITATIONS}

A limitation of this study was the small sample size of students and schools included as a convenient sample. This research focused only on grade 10 students and therefore it was not possible to describe how students' views changed during their learning. Only a paper and pencil instrument was used for data collection and there was no possibility to clarify students' responses at a later stage (e.g. using interviews). The students had minimal training in creating mind maps. As no follow-up interviews were held, it was not possible to estimate to what extent the lack of knowledge about mind maps held students back to create more in-depth maps. In this study, students' study habits, learning style, and orthographic knowledge were not considered.

\section{REFERENCES}

AAAS (American Association for the Advancement of Science). (2001). Project: 2061 Atlas of science literacy. Washington, DC: American Association for the Advancement of Science. http://www.project2061.org/publications/atlas/

Alavi, M. \& Leidner, D.E. (2001). Knowledge management and Knowledge Systems. Conceptual Foundations and Research Issues. MIS Quarterly, 25(1), 107-136.

Anderson, L. W. \& Krathwohl, D. R. et al (Eds.). (2001). A taxonomy for learning, teaching, and assessing: A revision of Bloom's Taxonomy of educational objectives. Allyn \& Bacon. Boston, MA (Pearson Education Group).

Ausubel, D. (1968). Educational psychology: A cognitive view. New York: Holt Rinehart: NewYork.

Bransford, J. D. Brown, A. L. \& Cocking, K. R. (2000). How people learn: brain, mind, experience, and school. National Academy Press: Washington, DC. 38.

Brinkmann, A. (2003). Graphical knowledge display-mind mapping and conceot mapping as efficient tools in mathematics education. Mathematics Education Review, 16, 35-48.

Bloom, B. S. \& Krathwohl, D. R. (1956). Taxonomy of Educational Objectives: The Classification of Educational goals, by a committee of college and university examiners. Handbook I: Cognitive Domain. NY, NY: Longmans, Green.

Buzan, T. (2005). Mind map handbook. Great Britain: Thorsons

Buzan, T. (2009a). Akıl haritaları: yaratıcılığınızı harekete geçirin ve dönüştürün. Hakan Öneş (Ed.). Istanbul: Boyut.

Buzan, T. (2009b). Muhteşem hafızanızla tanışın. Hakan Öneş (Ed.), İstanbul: Boyut.

Buzan, T. \& Buzan, B. (2007). The mind map book. Edinburg, England: BBC Active.

Chi, M. T. H. (2008). Three types of conceptual change: Belief revision, mental model transformation, and categorical shift. In International Handbook of Research on Conceptual Change, 1sr ed.; Vosniadou, S., Ed.; Routledge: New York, NY, USA, 61-82.
Cho, H. H. Kahle, J. B. \& Nordland, F. H. (1985). An investigation of high school biology text-books as sources of misconceptions and difficulties in genetics and some suggestions for teaching genetics. Science Education, 69(5), 707-719.

Cooper, M. M. Posey, A. L. \& Underwood, M. S. (2012). Core ideas and topics: Building up or drilling down? Journal of Chemical Education, 94, 531-548.

Dhindsa, H. S. Makarimi-Kasim \& Anderson, O. R. (2010). Constructivist-visual mind map teaching approach the quality of students' cognitive structure. Journal of Science Education and Technology, (20), 186-200.

Erdem, A. (2017). Mind maps as a lifelong learning tool. Universal Journal of Educational Research, 5(12), 1-7.

Freedman, S. W. (1994). Exchanging writing, exchanging cultures. Cambridge, MA. Harvard University Press.

Gafoor, A. K. \& Akhilesh, P. T. (2008). Misconceptions in physics among secondary school students. Journal of Indian Education, 34(1), 77-90.

Harlen, W. Devés, R. Garza, G. F. Léna, P. Millar, R. Reiss, M. Rowell, P. \& Yu, W. (2015). Working with Big Ideas of Science Education. Published by the Science Education Programme (SEP) of IAP.

Harlen, W. Devés, R. Garza, G. F. Léna, P. Millar, R. Reiss, M. Rowell, P. \& Yu, W. (2010). Principles and big ideas of science. Published by the Association for Science Education.

Hildebrand, D. L. (2018). Experience is not the whole story: The integral role of the situation in Dewey's democracy and education. Journal of Philosophy of Education, 52(2), 287300.

Krathwohl, D. R. (2002). A revision of Bloom's taxonomy: An overview. Theory Into Practice, 41(4), 212-218.

Kinchin, I. M. \& Hay, D. B. (2000). How a qualitative approach to concept map analysis can be used to aid learning by illustrating patterns of conceptual development. Educational Research, 42(1), 43-57.

Kinchin, I. M. (2011) Visualising knowledge structures in biology: Discipline, curriculum and studnets understanding. Journal of Biology Education, 45(4), 183-189.

Krajcik, J. \& Delen, I. (2017a). Engaging learners in STEM education. Estonian Journal of Education, 5(1). https://doi. org/10.12697/eha.2017.5.1.02b

Krajcik, J. \& Delen, I. (2017b). How to support learners in developing usable and lasting knowledge of STEM. International Journal of Education in Mathematics, Science and technology, 5(1), 21-28. http://doi.org/10.18404/ ijemst.18663

National Research Council (2012). A Framework for K-12 Science education: Practices, crosscutting concepts, and core ideas. Washington, DC: The National Academic Press. http://doi. org(10.17226/13165/

National Research Council. (2007). Taking science to school: Learning and teaching science in grades $K-8$. Washington, DC: The National Academic Press. http://doi.or/10.17226/11625/

Novak, J. D. \& Gowin, D. B. (1984). Learning how to learn. Cambridge and New York; University Press. http://doi. org/10.1017/CBO9781139173468

OECD (2016). "Students' attitudes towards science and expectations of sciencerelated careers". In: PISA 2015 Results (Volume I): Excellence and Equity in Education, PISA, OECD Publishing, Paris. 
Potvin, P. \& Hasni, A. (2014). Interest, motivation and attitude towards science and technology at K-12 level: a systematic review of 12 years of educational research. Studies in Science Education, 50(1), 85-129.

Ruiz- Primo, M. A. (2000). On the use of concept maps as an assessment tool in science: What we have learned so far. Revista Electrónica de Investigación Educativa. 2(1), 29-52.

Schwendimann, B. A. (2015). Concept maps as versatile tools to integrate complex ideas: from kindergarten to higher and professional education. Knowledge management and E-learning: An International Journal, 7(1), 73-99.

Semilarski, H., Soobard, R., \& Rannikmäe, M. (2019). Modelling students perceived self-efficacy and importance towards core ideas in science education. Science Education International, 30(4), 261-273.

Soobard, R., Rannikmäe, M. (2015). Examining curriculum related progress using a context-based test instrument - a comparison of Estonian grade 10 and 11 students. Science Education International, 26(3), 263-283.

Soobard, R., Semilarski, H., Holbrook, J., \& Rannikmäe, M. (2018). Grade 12 Students' perceived self-efficacy towards working life skills and curriculum content promoted through science education. Journal of Baltic Science Education, 17(5), 838-850.

Stevens, S. Sutherland, L. \& Krajcik, J. S. (2009). The big ideas of nanoscale science and engineering. Arlington, VA: National Science Teachers Association Press.

Tavory, I. \& Timmermans, S. (2014). Abductive analysis: Theorizing qualitative research. The University of Chicago Press. Abduction and Method, 51-67.

Tayaben, J. L. (2018). Reflecting on the book of Alvesson and Skoldberg's Reflexive Methodology: New insights and its importance in qualitative studies. The Qualitative Report, 23(10), 2261-2263. https://nsuworks.nova.edu/tqr/vol23/ iss $10 / 2$

Teppo, M., Semilarski, H., Soobard, R., Rannikmäe, M. (2017). Grade nine students' learning motivation and interest towards science topics presented in different contexts. Estonian Journal of Education, 5(1), 130-170.

Thompson, P. (2000). Radical constructivism: Reflections and directions. In L. P. Steffe, \& P. Thompson Radical constructivism in action: Building on the pioneering work of Ernst von Glaserfield (pp. 412-448). London: Flamer Press.

Wilson, S. T. (2001). Research on history teaching. In V. Richardson (Eds.). Handbook of Research on Teaching (pp. 527-544). Washington, DC: American Educational Research Association.

You, H. S. Marshall, J. A. \& Delgado, C. (2018). Assessing students disciplinary and interdisciplinary understanding of global carbon cycling. Journal of Research in science Teaching, 55(3), 377-398. 